\title{
POLYLACTIC/POLYGLYCOLIC ACID COPOLYMER IS A GOOD CARRIER FOR BMP-2 ON BONE REGENERATION?
}

\author{
COPOLÍMERO DO ÁCIDO POLILÁTICO/POLIGLICÓLICO É UM BOM \\ CARREADOR PARA BMP-2 NA REGENERAÇÃO ÓSSEA?
}

\begin{abstract}
Alexandre Ladeira Veloso dos ANJOS ${ }^{1}$; Roble Casares PEREZ ${ }^{1}$; Bárbara Maciel BRAGA²; Mariza Akemi MATSUMOTO ${ }^{3}$; Roberta OKAMOTO ${ }^{3}$; Patrícia Pinto SARAIVA ${ }^{1}$; Andréia Aparecida da SILVA ${ }^{1}$; Thiago Amadei PEGORARO ${ }^{1}$

1. Pró-reitoria de Pesquisa e Pós-Graduação, Universidade do Sagrado Coração, Bauru, SP, Brasil; 2. Centro de Ciências da Saúde, Universidade do Sagrado Coração, Bauru, SP, Brasil; 3. Departamento de Ciências Básicas, Universidade Estadual Paulista "Júlio de Mesquita Filho", Araçatuba, SP, Brazil.ppbau@uol.com.br
\end{abstract}

\begin{abstract}
The aim of this work was to evaluate the role of polylactic /polyglycolic acid copolymer as carrier for BMP-2 on bone regeneration in rat calvarium. Forty five adult male rats underwent 5-mm critical defects in bone calvaria to be divided into three groups according to the filling materials:-Control-blood clot; PLGA-polylactic acid Polyglycolic/copolymer; PLGA + BMP-2 -polylactic acid Polyglycolic/copolymer associated with BMP-2. Sacrifice of animals occurred at 5, 15 and 30 days after surgery The evaluation of new bone formation was obtained by histomorphometry, while OPG and RANKL proteins were observed by immunohistochemistry. Statistical analysis was performed by means of nonparametric tests based on quantitative variables of independent samples. Considering the amount of newly formed bone, significant difference was detected between PGLA $(178,2 \pm 137,5 \mu \mathrm{m})$ and the other groups, at day 30. In PLGA + BMP-2 and control groups, the expression of RANKL was prevalent on the OPG in the periods of 15 and 30 days, suggesting a favorable condition for bone reabsorption in these periods. Therefore, immunoexpression of RANKL and OPG and bone formation observed in different groups and periods of analysis showed that the polylactic/polyglycolic acid copolymer does not act as a good carrier for BMP-2.
\end{abstract}

KEYWORDS: Bone tissue. Osteoprotegerin. RANKL. Immunohistochemistry.

\section{INTRODUCTION}

Bone morphogenetic proteins (BMPs) are known due to the satisfactory results in bone regeneration. In addition, BMPs are required for the maintenance of bone homeostasis in adulthood, as they maintain stem and osteoprogenitor cells niches (SCHMOEKEL et al., 2005).

Although BMP-2 is recognized as one of the most effective treatments for inducing bone formation (YAMAMOTO et al., 2003), there is evidence that the BMPs may reduce bone mass through induction of osteoclastogenesis activation (ITOH et al., 2001).

The treatment of osteoblastic cells with BMP-2 or RANKL results in the formation of tartrate-resistant acid phosphatase positive multinucleated cells (TRAP), indicating the formation and activation of cells responsible for resorption (GRANHOLM et al., 2013). On the other hand, in the absence of osteoblasts, BMP-2 appears to increase directly the formation and survival of the osteoclasts (TOTH et al., 2009).

The recognition of the effect of BMP-2 on the activation of osteoclasts also has some divergences, indicating that its action is dependent on the concentration of BMPs used (ITOH et al.,
2001). In small local concentrations, BMP-2 induces the formation of bone tissue, and its excess is not desirable due to adverse effects such as induction of immunological response (CHUANG et al., 2010). The carrier can modify the availability of this protein, leading to a better use of the substance by bone tissue (ITOH et al., 2001). Several techniques have been employed to control the release of growth factors (GF). Some of these techniques involve the encapsulation of the GFs with biodegradable polymers, which are broken down by promoting the slow release of these factors (BLACKWOOD et al., 2012).

Some types of carriers present polyesters in their composition since it provides better control in their process of degradation. The polylactic /polyglycolic acid copolymer (PLGA) is widely used due to its biodegrading rate, which is compatible with tissue remodeling (DANIELS et al., 1990).

Based on the characteristics of these materials, the aim of this study was to evaluate PLGA as a carrier for BMP-2 on bone regeneration and its influence on RANKL/OPG ratio. 


\section{MATERIAL AND METHODS}

This study was approved by the Ethical Committee for Animal Care of Sagrado Coração University (protocol $\mathrm{n}^{\circ}$ 8224140515). All experimental protocols involving animals' management were carried out in accordance with the Principals of laboratory animal care $(\mathrm{NIH})$, as well as of Brazilian Society of Laboratory Animal Science (COBEA). Forty-five male adult albinus Wistar rats, mean weight of $300 \mathrm{~g}, 2$ months of age, underwent surgical confectioning of critical bone defects ( $5 \mathrm{~mm}$ in diameter) in their calvarial bone to be distributed in four groups, according to the filling materials, as follows: a) blood clot - control group; b) Polylactic/polyglycolic acid copolymer powder (Fisiograft®-Ghimas SPA, Italy) - PLGA Group; c) Polylactic/polyglycolic acid copolymer associated with BMP2 - PLGA+BMP-2 Group. (PLGA plus $5 \mu \mathrm{g}$ BMP-2 (R\&D Systems, Inc., Minneapolis, MN, USA). After the addition of BMP-2 on the PGLA, mixing the components was immediately placed in the bone defect).

\section{Surgical procedures}

For the bone defects procedures, the animals were anesthetized with intramuscular ketamine (75 $\mathrm{mg} / \mathrm{kg}$ ) and xylazine $(10 \mathrm{mg} / \mathrm{kg})$, and infiltration of local anesthetic with $2 \%$ mepivacaine with 1:100.000 epinephrine (Scandicaine, Septodont, France), for hemostasis of the operative field.

After trichotomy of the animals' head and antisepsy with $1 \%$ polyvinylpyrrolidone, a linear longitudinal dermoperiostal incision at the calvarium was performed, in order to expose bone tissue. One defect was performed using a 5-mm diameter trephine bur (3i Implant Innovations, Inc., Palm Beach Gardens, Florida, USA) in the left side of the parietal bone under copious irrigation with $0.9 \%$ saline solution (Darrow, Rio de Janeiro, Brazil), and filled with the above mentioned materials.

The tissues were repositioned and sutured with nylon (Nylon 5.0, Mononylon, Ethicon, Johnson Prod, São José dos Campos, Brazil). Immediately after the surgery, the animals were given a single dose of Tramadol ( $5 \mathrm{mg} / \mathrm{kg}$, IP).

\section{Histological Analysis}

After 5, 15 and 30 days, the animals were sacrifice by means of intraperitoneal injection of barbiturates (Thiopental), at a dose of $150 \mathrm{mg} / \mathrm{kg}$, in association with lidocaine $(10 \mathrm{mg} / \mathrm{mL})$. The specimens were removed and immediately fixed in $10 \%$ formalin for 48 hours and demineralized in
4.7\% EDTA, pH7, for 28 days (Merck, Darmstadt, Germany). Five micrometers semi-serial coronal slices from the inner center of the circular defects were collected to be stained with hematoxylin and eosin (HE) and for immunohistochemistry.

\section{Histomorphometric analysis}

Four 40x magnification fields correspondent to the central area of the defects from each sample were captured and registered by light microscope. The newly formed bone matrix quantification (Dempster et al., 2013) was accomplished using Image J software $\mathrm{r} 1.46$ (developed by Wayne Rasband, National Institutes of Health, Bethesda, MD), using a 3000 pixels template containing 225 non-coincident points. Only the points coincident with the bone matrix were considered.

\section{Immunohistochemical analysis}

Paraffin was removed with xylene from serial sections which were rehydrated in graded ethanol, and then pre- treated in a microwave with $0.01 \mathrm{M}$ citric acid buffer $(\mathrm{pH} 6)$ for three cycles of 5 min each at $850 \mathrm{~W}$ for antigen retrieval. The material was preincubated with $0.3 \%$ hydrogen peroxide in phosphate-buffered saline (PBS) solution for $5 \mathrm{~min}$ for inactivation of endogenous peroxidase and then blocked with 5\% normal goat serum in PBS solution for $10 \mathrm{~min}$. The specimens were then incubated with anti-OPG (P-17) polyclonal primary antibody (Santa Cruz Biotechnology, Santa Cruz, CA, USA) at a concentration of $1: 100$ or anti-RANKL (c-20) polyclonal primary antibody (Santa Cruz Biotechnology, Santa Cruz, CA, USA) both at a concentration of 1:100. Incubation was carried out overnight at $4{ }^{\circ} \mathrm{C}$ in a refrigerator. This was followed by two washes in PBS for $10 \mathrm{~min}$. The sections were then incubated with biotin-conjugated secondary antibody anti-rabbit IgG (Vector Laboratories, Burlingame, CA, USA) at a concentration of 1:200 in PBS for $1 \mathrm{~h}$. The sections were washed twice with PBS, followed by the application of a preformed avidin-biotin complex conjugated to peroxidase (Vector Laboratories, Burlingame, CA, USA) for $45 \mathrm{~min}$. The bound complexes were visualized by application of a 0.05 $\%$ solution of 3-30-diaminobenzidine solution and counterstained with Harris hematoxylin. For control studies of the antibodies, the serial sections were treated with rabbit IgG (Vector Laboratories, Burlingame, CA, USA) at a concentration of 1:200 in place of the primary antibody. Additionally, internal positive controls were performed with each staining bath. 
The determination of immunolabeling levels for each antibody was performed semiquantitatively, using scores from 1 to 4 (1=absent, $\quad 2$ =weak, $3=$ moderate, $4=$ intense) (PEDROSA JUNIOR et al., 2009). The analysis was performed in 5 fields of the interface area, at a 40x magnification optical microscope (NikonEclipse 80i, Tokyo, Japan), by two calibrated evaluators in a double-blind system.

Bone histomorphometry data were assessed using the variance analysis test Levene's test, followed by the analysis of independent samples by Mann-Whitney test. Immunohistochemistry data were assessed using the variance analysis Levene's test, followed by the independent samples t-Student or Mann-Whitney tests, which were used in order to detect differences between control and NSAID groups for the same period and graft. After, the statistical difference among the periods for each group and protein was determined by ANOVA and Kruskal-Wallis non-parametric test, or ANOVA and Tukey test, according to the variance homogeneity. The level of statistical significance was set at $0.5 \%$.

\section{RESULTS}

\section{Morphological microscopic analysis}

In all groups, it was not observed the formation of new bone after 5 days. In this period, in all groups it could be noted the formation of scar tissue in the area of the defect, being the PLGA and PLGA+BMP-2 groups possible to notice the presence of biomaterial, surrounded by an inflammatory process. In the period of 15 days, the control group presented newly formed tissue in the connective tissue area of the defect, but a small amount of bone tissue formed in the margin. This margin area presents itself lined with osteoblasts and few reverse lines. At 30 days it could be noted an increase in the production of bone matrix, with medullar characteristic and intense vascularization (Figure 1, A-B).

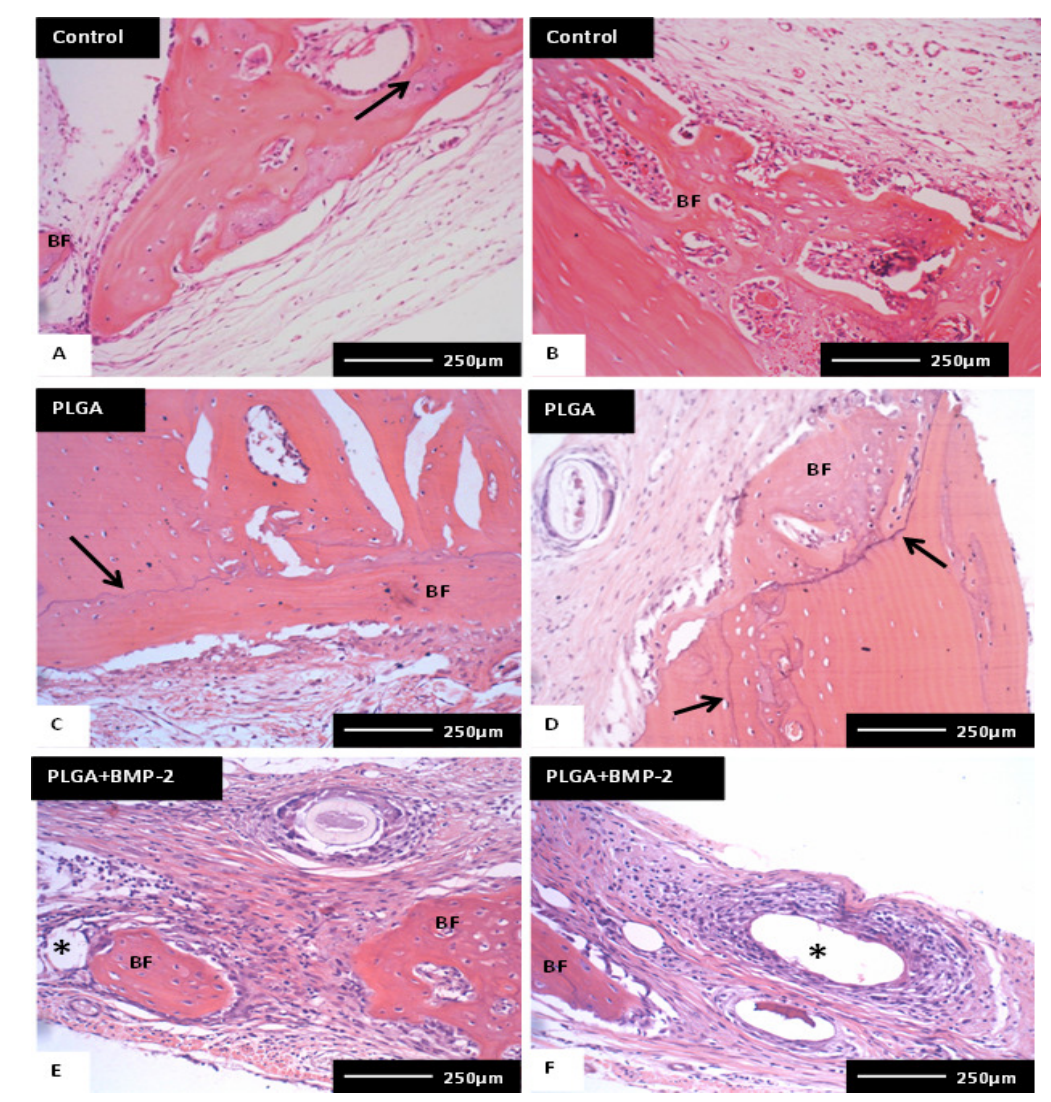

Figure 1. New bone formation was observed between the healing connective tissue at 15 days (A) and defect margin (B), with few lines of reversion lines. New bone formation (BF) was observed on the margins of the defect, with the presence of reverse lines (arrows), at 15 and 30 days in the PLGA group (C, D). In the PLGA+BMP-2 group, new bone formation (BF) and remnants of the implanted material $(*)$, both at 15 and 30 days (E, F) could be noted. Staining with H.E. 
At 15 days, the PLGA group showed newly formed immature bone tissue on the defect, and rollback lines indicating a remodeling process. At 30 days it could be noticed in the bone tissue formed, features of the organization of osteocytes around blood vessels. It was not observed remaining of the material in any periods (Figure 1, C-D). In the PLGA+BMP-2 Group, it could be noted newly immature bone tissue, as well as regions of the permanence of the material and inflammatory, infiltrate on its margin, in the two periods examined (Figure 1, E-F).

\section{Histomorphometric assessment}

Bone formation (B) in the region of defect has not been verified at 5 days. At 15 days B presented a similar pattern between the control and the other groups (PLGA and PLGA+BMP-2) in all periods, with no statistically significant differences $(\mathrm{p}>0.05)$. However, a difference $(\mathrm{p}<0.05)$ was detected in the period of 30 days between the PLGA group $(178.2 \pm 137.5)$ and control group $(8.2 \pm 7.7)$ and PLGA+BMP-2 group (4.8 \pm 10.7$)$ (Table 1).

Table 1. Statistical results from histomorphometric evaluation of calvarial bone

\begin{tabular}{llll}
\hline Periods & Bone $(\mu \mathrm{m})$ & Bone $(\mu \mathrm{m})$ & Bone $(\mu \mathrm{m})$ \\
& Control & PLGA & PLGA+BMP-2 \\
\hline 15 days & $15,2 \pm 15,5^{\mathrm{aA}}$ & $56,2 \pm 51,2^{\mathrm{aA}}$ & $8,6 \pm 15,6^{\mathrm{aA}}$ \\
30 days & $8,2 \pm 7,7^{\mathrm{aA}}$ & $178,2 \pm 137,5^{\mathrm{bA}}$ & $4,8 \pm 10,7^{\mathrm{aA}}$ \\
\hline
\end{tabular}

Different lowercase letters indicate statistical difference $(\mathrm{p}<0.05)$ between groups (rows). No significant statistical differences detected $(p>0.05)$ between the periods in each group, indicated by uppercase letters (columns). In the period of 5 days not observed formation of bone tissue.

\section{Immunohistochemistry}

Semi-quantitative analysis of the scores assigned to each protein markers analyzed (OPG and RANKL) is shown in Table 2. The statistical analysis carried out among the treatments occurred based on the different periods examined.

Table 2. Semi-quantitative analysis for OPG and RANKL

\begin{tabular}{lll}
\hline \multicolumn{1}{c}{ Tretments } & OPG & RANKL \\
\hline $\mathbf{5}$ days & +++ & + \\
Control & + & + \\
PLGA & + & - \\
PLGA+BMP-2 & & +++ \\
15 days & + & + \\
Control & +++ & ++ \\
PLGA & + & + \\
PLGA+BMP-2 & & - \\
30 days & - & +++
\end{tabular}

Semi-quantitative analysis scores, ranging from "-" to the absence of the immunoexpression to "+, ++, +++" for weak, moderate and intense, respectively.

At 5 days, the expression for OPG (Figure 2) predominated in control and was significantly different from the other groups $(\mathrm{p}<0.05)$, in which the expression was weak. At 15 days the PLGA+BMP-2 and control groups show similar expression $(p>0.05)$ but differed significantly $(\mathrm{p}<0.05)$ to the PLGA group, which presented the highest immunoexpression. At 30 days the expression of OPG in the PLGA group was intense $(\mathrm{p}<0.05)$ detected in the period, moderate in the PLGA+BMP-2 group, and absent in the control group. 


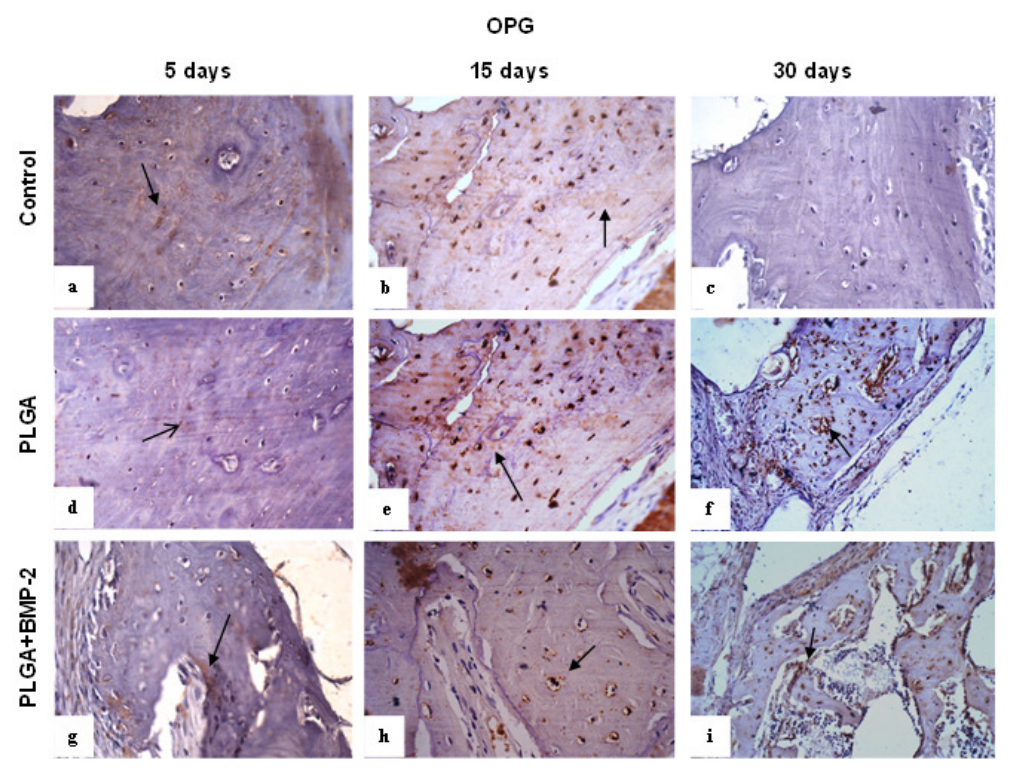

Figure 2. Immunohistochemistry expression for OPG observed in bone matrix (arrows) of the control group at 5 days (a). At 15 days, at the matrix, there was expression of the osteocytes (b), and at 30 days the expression was absent (c). For the PLGA group expression was weak in the matrix at 5 days (d). At 15 and 30 days, expression occurred on matrix and osteocytes, with moderate intensity (e-f). The PLGA+BMP-2 group presented weak expression at 5 and 15 days in bone matrix (g), and in the matrix and osteocytes (h), respectively. At 30 days the expression becomes moderate (i). 40x magnification.

For the RANKL (Figure 3), in the period of 5 days, the expression in the PLGA and control groups was similar $(\mathrm{p}>0.05)$, and in the PLGA+BMP-2 group was absent. In PLGA + BMP2 and control groups, the markup of RANKL was prevalent on the OPG in the periods of 15 and 30

days At 30 days, the immunoexpression in the PLGA group was absent.

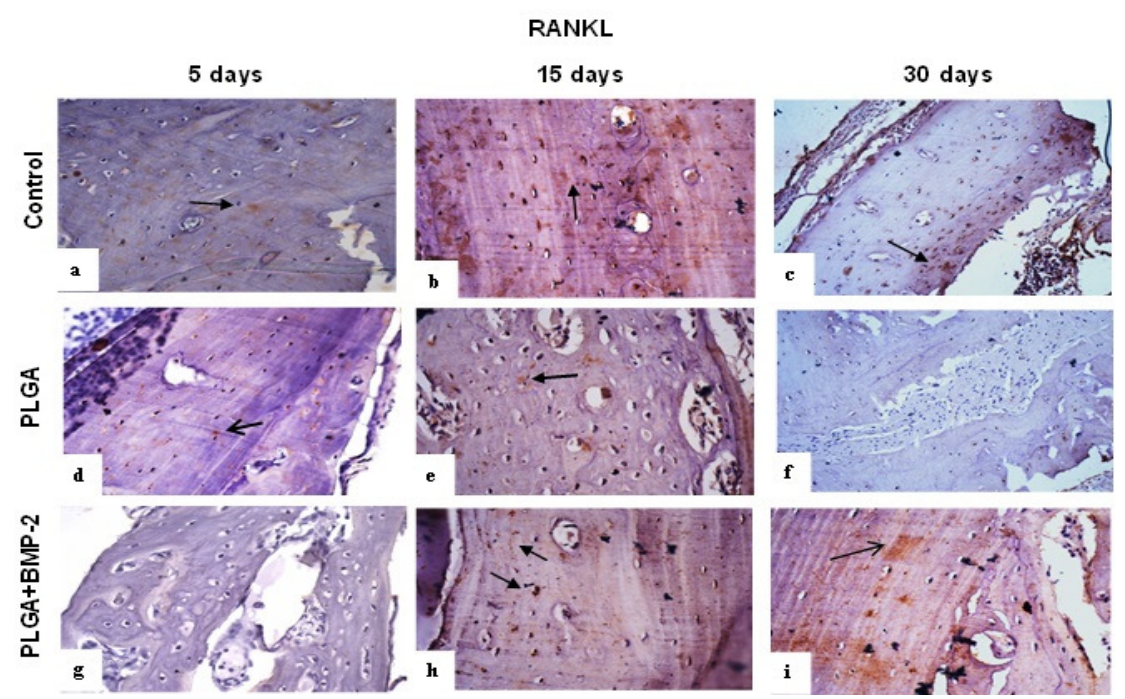

Figure 3. Immunohistochemistry expression for RANKL in the control group, at 5 days (a) was weak in bone matrix, becoming intense at 15 days, with expression at the bone matrix and osteocytes at 15 (b) and 30 days (c), with intense and weak expression, respectively. In the PLGA group expression occurred only in the bone matrix, at 5 (d) and 15 days (e), with weak expression. At 30 days (f) there was no expression. The PLGA+BMP-2 group, at 5 days, there was no expression (g). In 15 days, the expression occurred in the array and osteocytes moderately, becoming intense to 30 days (i), only in the matrix. 40x magnification. 


\section{DISCUSSION}

This work aimed to evaluate the behavior of polylactic/polyglycolic acid copolymer as a carrier for the growth factor BMP-2, in the process of bone regeneration. However, it was noted that the association of PLGA to BMP-2 showed worst results when compared to the use of PLGA alone.

The use of biomaterials that are associated with growth factors may help the healing process, being of fundamental importance to new bone formation (GAUTSCHI et al., 2007). Based on this concept, several biomaterials should be tested to evaluate their function as protein carrier. The choice of the materials for this study is justified by PLGA characteristics of biodegradability compatible with bone remodeling, and the BMP-2 act directly in the osteoblast differentiation (SEEHERMAN et al., 2005).

Although BMP-2 report good results in bone formation, its half-life is of about 6 to 7 minutes in non-human primates, due to enzyme degradation and rapid rate of depuration (SAITO \& TAKAOKA, 2003). Thus, to increase their effectiveness, BMPs must be combined with biocompatible vehicles as carriers to allow their gradual release over time.

Between the various types of biodegradable polymers available, poly-alpha hydroxyl acids, such as PLA, PGA, and their copolymer PLGA, have emerged as a choice to act as carriers (YASUDA et al., 1998).

In this study, critical bone defects were performed in calvarial bone of rats, so that there was no ability of spontaneous bone regeneration. These defects were filled by the clot, PLGA and PLGA associated with BMP-2, observed after 5, 15 and 30 days.

For verification of bone tissue activity, OPG/RANKL ratio was analyzed. The study of bone tissue resorption may occur by monitoring the proteins that actively participate in the activation of osteoclasts: the RANK/RANKL/OPG triad. The osteoclastogenesis is negatively regulated by OPG, which is a host that competes with RANK by the connection to RANKL (YASUDA et al., 1998). The control of the expression of these proteins provides important data for information of cellular activity of the target tissue, and consequently, of the repair process.

At day 5, it was not observed the formation of new bone tissue from the results obtained from morphological and morphometric analysis, but scar connective tissue in the defect area. Although it was not observed the formation of bone matrix, OPG expression was prevalent to the RANKL expression on control and PLGA+BMP-2 groups, and remained proportional in PLGA group. Therefore, in this initial phase of the repair process, the use of carrier + BMP-2 showed no difference from the control group. In this period it is still possible to view the presence of PLGA particles, indicating that degradation was partial.

At 15 days it is clear the formation of new bone, observed in all groups. RANKL labeling observed was predominant in control and PLGA+BMP-2 groups indicating osteoclastic activation. These data corroborate with morphometric data, which shows similar results in these two groups. At this stage, the presence of reversion lines in control and PLGA groups were observed, but were absent in the PLGA+BMP-2 group. Reversion lines represent bone remodeling process, characterizing a process of tissue reorganization. This reorganization activity in PLGA+BMP-2 group seems to have been late in relation to the other groups.

The results found at day 15 contradicts the findings of Pan \& Ding (2012), which stressed that despite being biocompatible, clinical application of PLGA alone disturbes bone regeneration by the lack of osteoconductivity. In our study, there was no difference in bone formation between PLGA group compared to the control group at day 15. Therefore, the use of PLGA does not appear to have hindered bone regeneration. The group that used the association of PLGA + BMP-2 also showed no difference in bone formation compared to the control group at day 15, although it was still possible to notice the presence of PLGA remnants in the area of the defect, which was not visible in the other treatments. At 30 days, the proteins analyzed showed a predominance of RANKL immunolabeling at control and PLGA+BMP-2 groups, while OPG was prevalent in the PLGA group. Immunolabeling of these proteins coincides with the formation of bone matrix. In the groups where RANKL predominated, poorer matrix formation was detected. The highest formation of bone tissue statistically significant was observed in the PLGA group, precisely in which there was a predominance of OPG.

Studies show different behaviors for the release of BMP-2, depending on the type of material used as a carrier. Kim et al. (2008), showed that the association of PLGA coated with apatite with BMP2 suspended in fibrin gel showed decreased protein release speed and increase in bone formation, in the same experimental model of the present study. Their results are contrary to ours, because although it still 
has been observed remnants of PLGA in the long term, PLGA did not present improved bone formation with the association with BMP-2.

Oest et al. (2007) also showed the difference between the carriers for BMP-2. The authors showed that the combination of BMP-2/PLGA with natural polymers, such as alginate hydrogel increases the femoral bone regeneration in a rat model. But the combinations of PLGA with synthetic polymers have been shown to decrease the rate of release of BMP-2 in vivo. Decreased release of BMP-2 can justify a lower control bone formation observed in this study.

Luvizuto et al. (2011) evaluated the influence of BMP-2 associated with the PLGA, among other biomaterials. As well as in this study, they did not observe better results when the growth factor has been associated with the PLGA. Another study (CHAPPUIS et al., 2012), however, noted positive results when there was the association of BMP-2 to an allogeneic graft. Therefore, these data confirm the inefficiency of PLGA as carrier material for bone augmentation.

Specific reports could also justify the absence of positive results when there was the addition of BMP-2 to PLGA verified in this experiment. ITOH et al. (2001) and GRANHOLM et al. (2013) indicate that the activity of BMP-2 can be associated with the activation of the osteoclastogenesis process. This activity was observed in the periods of 15 and 30 days of the study, in which the expression of RANKL predominated on the OPG.

The best results for the formation of bone tissue on this study took place in the presence of the PLGA alone, although other study (LÜ et al., 2009) indicate that the polymer, by itself, would be inert, and do not promote a biological response in the bone tissue. These data corroborate with the results found by Luvizuto et al. (2011) showing that the presence of BMP-2 decreases the osteoconductive properties of PLGA.

The comparison between the analyzed groups shows that the PLGA increases bone formation when used without the association of BMP-2. When BMP-2 is incorporated into the PLGA, it apparently causes a delay in the healing process, rather than improve healing.

Additional studies in different types of bone defects and animal models, must be performed in order to attest the effectiveness of the PLGA as carrier for BMP-2.

\section{CONCLUSION}

The polylactic/polyglycolic acid copolymer presents osteoinductive properties; however, does not behave properly as a good carrier for BMP-2.

RESUMO: O objetivo deste estudo foi avaliar o copolímero do ácido polilático/poliglicólico como carreador para BMP-2 na regeneração óssea da calvária de ratos. Foram utilizados 45 ratos adultos machos. Defeitos ósseos críticos de $5 \mathrm{~mm}$ de diâmetro foram realizados com uma broca trefina na calvária dos animais. Os animais foram divididos em três grupos, de acordo com o material de notas para preenchimento dos defeitos: Controle - coágulo; PLGA - copolímero ácido polilático/poliglicólico; PLGA + BMP-2 - copolímero do ácido polilático/poliglicólico associado a BMP-2. O sacrifício ocorreu aos 5, 15 e 30 dias após a cirurgia. A avaliação da neoformação óssea foi obtida por histomorfometria, enquanto a análise de marcação para as proteínas OPG e RANKL foi observada por imunohistoquímica. Análises estatísticas foram realizadas por meio de testes não paramétricos de variáveis quantitativas em amostras independentes. Com relação à quantidade de tecido ósseo neoformado, observou-se diferença estatística significante entre o grupo PLGA $(178,2 \pm 137,5 \mu \mathrm{m})$ e os demais, no período de 30 dias. Nos grupos PLGA+BMP-2 e Controle, a marcação de RANKL foi predominante sobre a marcação de OPG nos períodos de 15 e 30 dias, evidenciado uma condição favorável para a reabsorção óssea nestes períodos. Portanto, a marcação de RANKL e OPG, e a formação óssea observada nos diferentes grupos e tempos de análise mostrou que o copolímero de ácido polilático/poliglicólico não atua como um bom carreador para BMP-2.

PALAVRAS-CHAVE: Reparo ósseo. BMP-2. Osteoprotegerina. RANKL. Imunohistoquímica.

\section{REFERENCES}

BLACKWOOD, K. A.; BOCK, N.; DARGAVILLE, T. R.; WOODRUFF, M. A. Scaffolds for growth factor delivery as applied to bone tissue engineering. International Journal of Polymer Science, Article ID 174942, 25 pages, 2012. http://dx.doi.org/10.1155/2012/174942 
CHAPPUIS, V.; GAMER, L.; COX, K.; LOWERY, J. W.; BOSSHARDT, D.D.; ROSEB, V. Periosteal BMP-2 activity drives bone graft healing. Bone, v. 51, p. 800-809, 2012. http://dx.doi.org/10.1016/j.bone.2012.07.017

CHUANG, C. K.; LI, K. J.; LIN, C. Y.; CHANG, Y. H.; YEN, T. C.; HWANG, S. M.; SUNG, L. Y.; CHEN, H. C.; HU, Y. C. Xenotransplantation of human mesenchymal stem cells into immunocompetent rats for calvarial bone repair. Tissue Engineering Part A, v. 16, p. 479-488, 2010.

http://dx.doi.org/10.1089/ten.TEA.2009.0401

DANIELS, U.; CHANG, M. K.; ANDRIANO, K. P. Mechanical properties of biodegradable polymers and composites proposed for internal fixation of bone. Journal of Applied Biomaterials, v. 1, p. 57-78, 1990. http://dx.doi.org/10.1002/jab.770010109

GAUTSCHI, O. P.; FREY, S. P.; ZELLWEGER, R. Bone morphogenetic proteins in clinical applications. ANZ Journal of Surgery, v. 77, p. 626-631, 2007. http://dx.doi.org/10.1111/j.1445-2197.2007.04175.x

GRANHOLM, S.; HENNING, P.; LINDHOLM, C.; LERNER, U. H. Osteoclast progenitor cells present in significant amounts in mouse calvarial osteoblast isolations and osteoclastogenesis increased by BMP-2. Bone, v. 52, p. 83-92, 2013. http://dx.doi.org/10.1016/j.bone.2012.09.019

ITOH, K.; UDAGAWA, N.; KATAGIRI, T.; IEMURA, S.; UENO, N.; YASUDA, H.; HIGASHIO, K.; QUINN, J.M.; GILLESPIE, M. T.; MARTIN, T. J.; SUDA, T.; TAKAHASHI, N. Bone morphogenetic protein 2 stimulates osteoclast differentiation and survival supported by receptor activator of nuclear factor kappa B ligand. Endocrinology, v. 142, p. 3656-3662, 2001. http://dx.doi.org/10.1210/endo.142.8.8300

KIM, S. S.; GWAK, S. J.; KIM, B. S. Orthotopic bone formation by implantation of apatite-coated poly(lactide-co-glycolide)/hydroxyapatite composite particulates and bone morphogenetic protein-2. Journal of Biomedical Materials Research, v. 87, p. 245-253, 2008. http://dx.doi.org/10.1002/jbm.a.31782

LÜ, J. M.; WANG, X.; MARIN-MULLER, C.; WANG, H.; LIN, P. H.; YAO, Q.; CHEN, C. Current advances in research and clinical applications of PLGA-Based nanotechnology. Expert Review of Molecular Diagnostics, v. 9, p. 325-341, 2009. http://dx.doi.org/10.1586/erm.09.15

LUVIZUTO, E. R.; TANGL, S.; ZANONI, G.; OKAMOTO, T.; SONODA, C. K.; GRUBER, R.; OKAMOTO, R. The effect of BMP-2 on the osteoconductive properties of $\beta$-tricalcium phosphate in rat calvarial defects. Biomaterials, v. 32, p. 3855-3861, 2011. http://dx.doi.org/10.1016/j.biomaterials.2011.01.076

OEST, M. E.; DUPONT, K. M.; KONG, H. J.; MOONEY, D. J.; GULDBERG, R. E. Quantitative assessment of scaffold and growth factor-mediated repair of critically sized bone defects. Journal of Orthopaedic Research, v. 25, p. 941-950, 2007. http://dx.doi.org/10.1002/jor.20372

PAN, Z.; DING, J. Poly(lactide-co-glycolide) porous scaffolds for tissue engineering and regenerative medicine. Interface Focus, v. 2, p. 366-377, 2012. http://dx.doi.org/10.1098/rsfs.2011.0123

PEDROSA JUNIOR, W.; OKAMOTO, R.; FARIA, P. E.; ARNEZ, M. F.; XAVIER, S. P.; SALATA, L. A. Immunohistochemical, tomographic and histological study on onlay bone graft remodeling. Part II: calvarial bone. Clinical Oral Implants Research, v. 20, p. 1254-1264, 2009. http://dx.doi.org/10.1111/j.16000501.2009.01747.x

SAITO, N.; TAKAOKA, K. New synthetic biodegradable polymers as BMP carriers for bone tissue engineering. Biomaterials, v. 24, p. 2287-2293, 2003. https://doi.org/10.1016/S0142-9612(03)00040-1

SCHMOEKEL, H. G.; WEBBER, F. E.; SCHENSE, J. C.; GRATZ, K. W.; SCHAWALDER, P.; HUBBELL, J.A. Bone repair with a form of BMP-2 engineered for incorporation into fibrin cell in growth matrices.

Biotechnology and Bioengineering, v. 89, p. 253-262, 2005. http://dx.doi.org/10.1002/bit.20168 
SEEHERMAN, H.; WOZNEY, J. M. Delivery of bone morphogenetic proteins for orthopedic tissue regeneration. Cytokine Growth Factor Reviews, v. 16, p. 329-345, 2005.

http://dx.doi.org/10.1016/j.cytogfr.2005.05.001

TOTH, J. M.; BODEN, S. D.; BURKUS, J. K.; BADURA, J. M.; PECKHAM, S. M.; MCKAY, W. F. Short term osteoclastic activity induced by locally high concentrations of recombinant human bone morphogenetic protein-2 in a cancellous bone environment. Spine, v. 34, p. 539-550, 2009.

https://doi.org/10.1097/BRS.0b013e3181952695

YAMAMOTO, M.; TAKAHASHI, Y.; TABATA, Y. Controlled release by biodegradable hydrogels enhances the ectopic bone formation of bone morphogenetic protein. Biomaterials, v. 24, p. 4375-4383, 2003.

https://doi.org/10.1016/S0142-9612(03)00337-5

YASUDA, H.; SHIMA, N.; NAKAGAWA, N.; MOCHIZUKI, S.I.; YANO, K.; FUJISE, N.; SATO, Y.; GOTO. M.; YAMAGUCHI. K.; KURIYAMA. M.; KANNO, T.; MURAKAMI, A.; TSUDA, E.;

MORINAGA, T.; HIGASHIO, K. Identity of osteoclastogenesis inhibitory factor (OCIF) and osteoprotegerin (OPG): a mechanism by which OPG/OCIF inhibits osteoclastogenesis in vitro. Endocrinology, v. 139, p. 1329-1337, 1998. http://dx.doi.org/10.1210/endo.139.3.5837 